\title{
Can training prisoners through The Clink restaurants reduce reoffending?
}

\section{Tracy Harkison and Christopher Moore}

\begin{abstract}
Tracy is the programme leader for the Bachelor of International Hospitality Management at Auckland University of Technology, New Zealand. Her research passions are hospitality education and the co-creation of luxury accommodation experiences.
\end{abstract}

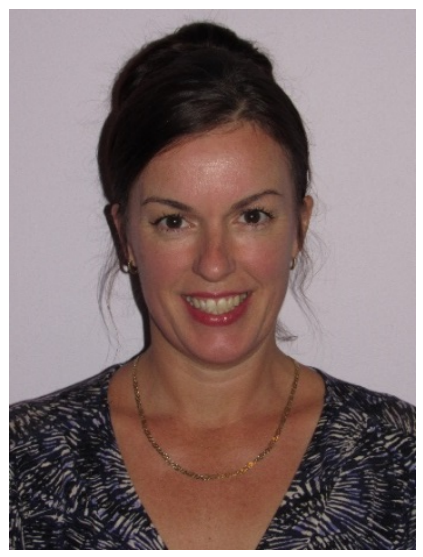

Chris Moore has previously worked for Fenwick Ltd as head of Group restaurants. Prior to this, he worked at Harrods Ltd as restaurants general manager. He has also worked for the Hilton Hotel Group in the UK and Holland, and trained with the Holiday Inn Hotel Group in New York. In 2010, he was appointed chief executive of The Clink Charity as part of a long-term plan to expand

\author{
The following is an interview conducted in May 2019 in the U.K. between \\ Dr Tracy Harkison, a senior lecturer at AUT, and Chris Moore, CEO of The \\ Clink Charity. The interview transcript was edited by Prof Alison McIntosh.
}

\section{Tracy Harkison}

Can you please explain to me how this initiative came to be established?

\section{Chris Moore}

The challenge was that the reoffending rates in the UK are really high. Fortyeight percent of people that leave prison go back within the first year. The catering manager at one of the prisons in the UK was cooking 3,000 hot meals a day for the prisoners in that prison, using prisoners, and in those days $60 \%$ of those prisoners were reoffending and returning back within the first year. He wasn't happy with this and wanted to do something about it so he trained his staff up as trainers and assessors. They started delivering accredited City and Guilds national vocational qualifications (NVQ) and the prisoners did really well and they got those qualifications. They left with their certificates and skills, very proud, but sadly, it didn't make any difference to the number returning.

So the next step was, he started to introduce employers. He did something called 'Gourmet Lunches' where once a month he'd bring in prospective employers and introduce them to prisoners who were qualified and nearing release. They'd have a nice meal, have a chat, get work, and not as many [prisoners] came back. So in 2009 the prison was going through an expansion and he asked if they could turn a new staff mess into a fine dining restaurant. He went out with a whole group of people and raised a lot of money and built a fine dining restaurant, and that's how it started.

Tracy

What was the purpose?

\section{Chris}

The whole purpose of it is to reduce reoffending, but the by-product of that is, the hospitality industry in the UK has got a major skills shortage and it's really hard to find qualified people so you've got a really huge untapped workforce of 82,000 men and 4,000 women in England and Wales - Scotland and Northern Ireland are separate - who we can train up and get into work. They're a 
the prisoner training concept across Her Majesty's Prison Service. The Clink Charity's main objectives are to change attitudes, transform lives and create second chances.

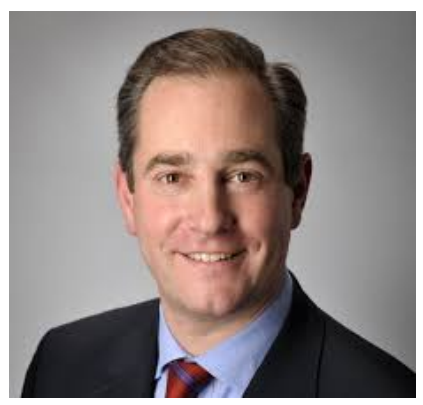

credible solution to the skills shortage.

\section{Tracy}

Did the establishment receive good initial support for its development?

\section{Chris}

It was set up by a government employee who was the prisons catering manager. He went out and was introduced to some philanthropic individuals, some grant-maintaining trusts and they raised some money, but he wasn't allowed to operate the restaurant as a government employee. I suppose, before then, obviously working in a prison they're very risk-adverse for security reasons and normally you don't have people coming into the heart of the prison daily. In the year you'd probably have 100 people a year coming through the main gates. The restaurant actually has 100 people a day coming through the main gates at each of its prisons, so that's quite a big risk. Having operated the prison for six months, a charity was formed and one of the first things they did was find me, so it went from there.

\section{Tracy}

In what ways do you think hospitality is a suitable industry to assist prisoners' rehabilitation?

\section{Chris}

If you work in the hospitality industry it's a way of life, not a job, because you're working anti-social hours, so generally the people you work with you play with as well and they're a family; you become tight-knit. So it's really good because, going back to my original statement of "Lots of people are in prison because they've no family or the wrong family", effectively catering is a family so it works really well. There's a major skills shortage, the industry's growing - I think it's $6 \%$ a year at the moment - so there's no problem with finding the jobs at all.

\section{Tracy}

Why do you think hospitality is so important?

\section{Chris}

For the graduates to work in [...] because it's a very unforgiving industry. It's a family and everyone comes to it with their own unique skills and they can find their place. It's a very diverse, varied [...]. You can be a porter in the background talking to anybody or in a stockroom, or you can be like an actor on stage and running around the restaurant or the reception. So I think it's good; it's hard work; it's long hours; it's anti-social hours. Again, a lot of crimes happen in anti-social hours so you're keeping them busy, and there's a major skills shortage. And I think our model isn't unique to the hospitality industry. We keep encouraging the government to look at other industries that have got skills shortages, so construction or hairdressing, it doesn't really matter what it is, but by offering an integrating programme for an industry that has a skills shortage, it will work.

\section{Corresponding author}

Tracy Harkison can be contacted at: tracy.harkison@aut.ac.nz 